\title{
Remote Sensing and the Rancher: Linking Rancher Perception and Remote Sensing
}

\author{
Rex J. Rowley, ${ }^{1}$ Kevin P. Price, ${ }^{2}$ and Jude H. Kastens ${ }^{3}$ \\ Authors are ${ }^{1} \mathrm{PhD}$ Candidate, Department of Geography, University of Kansas, Lawrence, KS 66045; ${ }^{2}$ Professor, Department of Geography, \\ University of Kansas, Lawrence, KS 66045; and ${ }^{3}$ Senior Research Assistant, Kansas Applied Remote Sensing (KARS) Program, University of Kansas, \\ Lawrence, KS 66045.
}

\begin{abstract}
In recent years, steps have been taken to implement a new crop insurance program for rangeland and pasture. Unlike traditionally insured row and cereal crops, which have directly measurable yields, there is no such simple, ideal yield standard for rangeland and pasture because of uncertainties regarding how to generally and objectively quantify annual production. With remotely sensed imagery acquired by the Advanced Very High Resolution Radiometer transformed to the Normalized Difference Vegetation Index (NDVI), we derived a proxy relative yield measurement for rangeland and pasture vegetation. This proxy measurement could potentially solve a critical component of the yield quantification problem facing implementation of a rangeland insurance program. In order to evaluate this proxy measurement and how ranchers might accept it, we surveyed a group of Kansas and Oklahoma ranchers to determine how their perception of rangeland productivity compared to NDVIbased proxy measurements of rangeland productivity in the surveyed rancher's county for the growing seasons of 1999-2003. At the scale of the ranch, correlation analysis showed that perception was not highly correlated with the satellite indices. Higher correlations were observed when perception data were aggregated and compared to rangeland indices at the county and study area levels, with performance comparable to using precipitation information. The year with the strongest correlation was the worst drought year of the 5 , a desirable outcome in the context of an insurance program. Results from this case study provide some support for using remote sensing data in a national rangeland and pasture insurance program. Such a program would be an important new risk mitigation tool for ranchers.
\end{abstract}

\section{Resumen}

En años recientes se han tomado pasos para implementar un nuevo programa de seguro agrícola para praderas nativas y pastizales. A diferencia de los cultivos en surcos o cereales tradicionalmente asegurados, los cuales tienen rendimientos que se pueden medir directamente, en pastizales y praderas nativas no hay un rendimiento estándar ideal de referencia tan simple, debido a la incertidumbre de como cuantificar, en forma generalizada y objetivamente, la producción anual. Con imágenes de sensores remotos adquiridas por el Radiómetro Avanzado de Muy Alta Resolución y transformadas al Índice Normalizado de Diferencia de Vegetación (NDVI), derivamos una medición substituta del rendimiento relativo de la vegetación de pastizales y praderas naturales. Esta medida substituta pudiera potencialmente resolver un componente crítico del problema de cuantificación del rendimiento que encara la implementación de un programa de seguro en pastizales. Para evaluar esta medida substituta, y como los productores pudieran aceptarla, entrevistamos un grupo de ganaderos de Kansas y Oklahoma para determinar como sus percepciones de la productividad del pastizal se equiparan con las mediciones substitutas de la productividad del pastizal basadas en NDVI del municipio de los ganaderos entrevistados durante las estaciones de crecimiento de 1999 a 2003. A la escala de rancho, el análisis de correlación mostró que la percepción no estuvo altamente correlacionada con los índices del satélite. Las más altas correlaciones se observaron cuando los datos de percepción se agregaron y compararon con los índices del pastizal a nivel de municipio y área de estudio, con un resultado comparable a usar información de precipitación. El año con la más alta correlación fue el año con la peor sequía de los cinco evaluados, un resultado deseable en el contexto de un programa de seguro. Los resultados proveen algo de soporte para usar datos de sensores remotos en un programa nacional de seguro de pastizales y praderas nativas. Tal programa sería una herramienta nueva importante de mitigación de riesgo para los ganaderos.

Key Words: crop insurance, forage productivity, human perception, NDVI, phenology, rangeland insurance

\section{INTRODUCTION}

Components of this study were supported by the National Science Foundation under Grant DEB-0119618. Any opinions, findings, and conclusions or recommendations expressed in this material are those of the authors and do not necessarily reflect the views of the National Science Foundation.

At the time of this research, Rowley was a graduate research assistant at the Kansas Applied Remote Sensing (KARS) Program at the University of Kansas.

Correspondence: Rex J. Rowley, Department of Geography, University of Kansas, Lawrence, KS 66045. Email: rjrowls@ku.edu

Manuscript received 3 August 2006; manuscript accepted 8 May 2007.
No: if there is a dread in the county, it is not of dark skies but of the opposite, of clear skies, days and days of clear skies, of a drought nobody escapes, not even the shopkeepers.

—William Least Heat-Moon, PrairyErth (a deep map)

Life on the land inevitably involves struggles with nature. In the previous quotation, William Least Heat-Moon wants the reader to understand that the real dread for farmers, ranchers, 
and the businesses they patronize in Chase County, Kansas, is not tornadoes or hail but instead the torment of relentless drought. The same could be said for every other county on the prairie. Farmers have coped with this dread, in part, through federally sponsored crop insurance. But only recently has the US Department of Agriculture's (USDA's) Risk Management Agency (RMA) considered a program to insure rangeland and pasture in a similar manner (Cameron 2002). With the passing of recent legislation, the implementation of such a program has become mandatory and one of the highest priorities for RMA (ARPA 2000; RMA 2004).

One of the difficulties with RMA's efforts to date in a pilot program for rangeland insurance in Montana stems from the fact that range vegetation is not a typical crop, like wheat or corn, that is harvested and measured; range vegetation is, instead, forage that is harvested by grazing animals (Looker 2003). Data from satellite imagery can provide a measure, remotely, of rangeland vegetation growth characteristics (Tucker et al. 1985; Tueller 1989; Price et al. 1992; Wang et al. 2001). Specifically, the Normalized Difference Vegetation Index (NDVI) remote sensing imagery from the Advanced Very High Resolution Radiometer (AVHRR) in conjunction with geographic information systems can be used to establish a proxy yield measurement for rangeland vegetation (i.e., how well the vegetation was growing in a particular year relative to a historical average; see Rowley 2005). This article will show how effectively these measurements perform through a quantitative comparison of NDVI-based index scores with ranchers' perception of rangeland productivity, which was collected through a survey of a group of Kansas and Oklahoma ranchers likely to hold interest in a rangeland insurance program but not yet directly impacted by RMA's pilot program. Positive correlation and agreeability between rancher perception and NDVI-based rangeland insurance indices support the use of these data in indemnity determinations in rangeland and pasture insurance. Furthermore, an acceptable implementation of such an insurance program increases management options for ranchers and has the ability to provide an additional measure of economic security in the face of potential natural calamities.

\section{CURRENT DEVELOPMENTS IN RANGELAND INSURANCE}

A typical crop insurance program, such as the Actual Production History (APH) program, requires a yield for the growing season and a historical average to use as a comparison. The yield is usually based on a farm-level measurement, and the historical average is calculated from the records of the same measurement over time. From the comparison, a determination of loss over a particular growing season can be made (Barnett 2004). The range and pasture pilot program in Montana (ongoing since 1999) is an example of a Group Risk Plan (GRP). GRP insurance programs have the same 2 basic requirements as an APH program, only a GRP yield is based on an area-level measurement, usually the county. This means that a single yield number for the county, as estimated by the USDA National Agricultural Statistics Service (NASS), is compared to the average yield over time for that county in order to determine whether a loss occurred (Barnett 2000; RMA 2003). Every farmer or rancher who buys GRP insurance that year will receive an indemnity payment if the county average is below the trigger level chosen at the time insurance is purchased, even if their actual yield is above normal. The opposite, however, is also true. A payment theoretically could be withheld even if the farmer or rancher had a horrible crop. Because of this possibility and the likelihood of inconsistency, GRP insurance is usually less expensive than individualcoverage crop insurance (RMA 2003). Numerically, cost reduction is possible because county-level yields are generally less variable over time than farm-level yields, allowing for lower premium rates.

Since rangeland forage is not cut and measured at harvest or sale, as are traditional row crops, meeting the standard requirements for crop insurance has been difficult. In the Montana pilot program, RMA uses proxy crops as the method of determining loss. These proxy crops are those with yields already estimated by NASS that are expected to have similar productivity to rangeland vegetation. This use of proxy crops provides a seemingly adequate representation of production on rangeland, but little confidence exists among ranchers in NASS estimates and the way they are calculated (Looker 2003). A more direct measurement of the rangeland itself presumably would provide a more trusted result. A remote sensing index that accurately reflects "relative to normal" rangeland production can help meet rangeland insurance program requirements, thereby facilitating resolution to program design problems faced by RMA.

It is important to note that like any other indexed yield proxy, an NDVI-based rangeland insurance index offers only a partial solution to the yield requirement for a rangeland insurance program. However, it addresses the most difficult component, namely, appropriate quantification of local rangeland production variability. Although several studies have established a linkage between NDVI and live plant biomass/ productivity (Tucker et al. 1985; Hobbs 1995; Reeves et al. 2001; Al-Bakri and Taylor 2003; Wang et al. 2005), the amount of utilizable (by livestock) biomass is not clear. Consequently, to complete informational needs for a rangeland insurance program, unitless "deviations from normal" scores have to somehow be translated into units of production/dollars. For example, animal unit month information (such as can be obtained from the Natural Resource Conservation Service's STATSGO and SSURGO data) can be used to establish baseline "yields," and rating and adjustment information from other crop insurance programs in the same region can be used to transfer "deviations from normal" values to estimates of loss percentage.

\section{STUDY AREA}

To investigate how well the NDVI-based rangeland insurance indices computed at the county level correlate with rancher perception, we sent out surveys to a group of ranchers in Kansas and Oklahoma. Specifically, we targeted 53 ranchers on the Comanche Pool Prairie Resource Foundation (Comanche Pool, or CP) mailing list. Five ranchers in the Red Hills region of Kansas and Oklahoma who wanted to learn more about the 


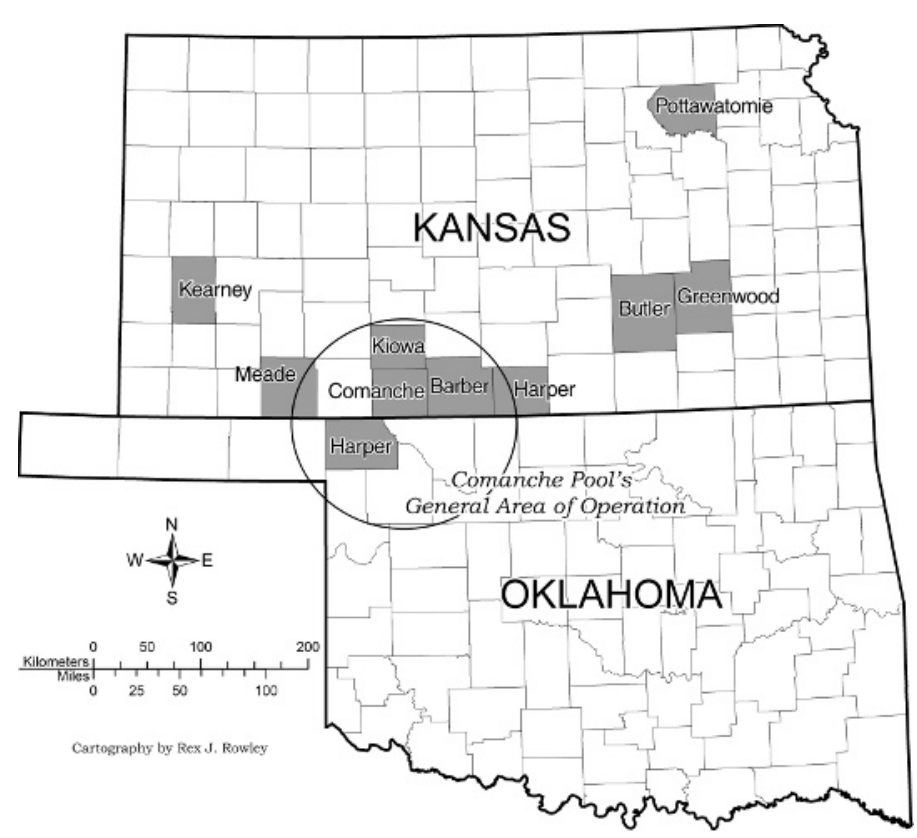

Figure 1. Study area counties and general area of operation for the Comanche Pool Prairie Resource Foundation. This is the core area to which the surveys were sent, but others living well outside this area are involved in Comanche Pool (CP), and so responses came from other areas of Kansas. The majority of responses, however, represent ranch land in this core area. Study area counties shaded in gray. Map adapted from CP (no date).

ranching business and rangeland ecosystems originally organized the Comanche Pool in 1998. The organization was formalized a year later with a mission to "provide demonstrations, education and consultation to regenerate the natural resources and to promote the economic growth of the rural community" (CP, no date). Although the CP's main service area is in and around the Red Hills (Fig. 1), other people interested in range management attend their functions and become part of their mailing list (personal communication, 20 October 2004). The majority of our survey responses, however, represented ranchland in the $\mathrm{CP}$ core area. The $\mathrm{CP}$ mailing list was an appropriate target for our study because of their likely interest, as reflected in their mission statement, in new rangeland management options, such as rangeland insurance. In addition, these ranchers had not yet been impacted by RMA's Montana pilot program, which allowed them to respond to the survey without being biased by past experience with that program's other proxy indemnity triggers.

The collected responses to the survey led to a spatially disjointed study area consisting of 10 counties in Kansas and Oklahoma (Fig. 1). These counties range from 3 (Pottawatomie, Butler, and Greenwood) that lie in the Flint Hills, growing mainly big (Andropogon gerardii Vitman) and little bluestem (Schizachyrium scoparium Michx.) grasses with some Indian grass (Sorghastrum nutans [L.] Nash) and switchgrass (Panicum virgatum L.) and supporting one of the most productive grazing areas in the country; 6 more study area counties (Kiowa, Comanche, Barber, Harper, and Meade in Kansas and Harper in Oklahoma) in the Red Hills, an area of mixed prairie between the tallgrass prairies to the east and the short-grass prairies of the west; and 1 county (Kearney) in the short-grass blue grama-buffalograss (Bouteloua gracilis [H.B.K.] Lag. ex Steud. and Buchloe dactyloides [Nutt.] Engelm.) and sandsage prairie typical of the High Plains (Schoewe 1949; Küchler 1974; Buchanan and McCauley 1987).

In collecting survey data, we faced the dilemma of needing to tie the anonymous surveys sent to ranchers back to geographic locations of the ranches they describe without being so overly specific and personal as to discourage response. Having the ranchers provide the county (or counties) in which their rangelands reside provided a solution to this dilemma. In addition, a county-based analysis follows the framework already established in the GRP rangeland pilot program currently underway.

\section{METHODS}

\section{Deriving Rangeland Insurance Indices From Satellite Data}

The satellite data used to compute the rangeland insurance indices originated from the AVHRR maximum value NDVI composites produced over a 14-day period (Holben 1986) for the conterminous United States. This data set was processed at the US Geological Survey's EROS Data Center in Sioux Falls, South Dakota, and is updated weekly (Holben 1986; Eidenshink 1992, 2006). A 15-year data set (1989-2003) of these composites was provided by the Kansas Applied Remote Sensing Program. In its entirety, our data set included 52 weekly, NDVI composites for each of 15 years (780 total images) extracted for our study area.

Given that survey responses were geographically tied to the county and given our desire to mimic a GRP-like crop insurance program, we derived a set of rangeland insurance indices from AVHRR NDVI data that measured vegetation "greenness" (a term used in reference to the amount of photosynthetically active vegetation) in a particular county and for a particular year as compared to historical average greenness. To do this, we first extracted only the pixels from the satellite data set that represented areas of predominantly rangeland vegetation, employing "percent rangeland" values derived from the National Land Cover Dataset (Vogelmann et al. 2001) for masking purposes (specifically, a 95\% threshold was used to determine pixel inclusion). We then calculated a spatial average of NDVI values for the extracted rangeland pixels within each of the study area counties and for each compositing period. The result was a series of tables containing a single NDVI value per county per weekly composite period for each of the 15 years of data.

With the weekly county-level greenness numbers, we characterized the growing season for each county by year. In order to determine a "normal" growing season, we calculated the 15-year average weekly NDVI time series for each county. We then computed 4 separate indices, each representing a particular time period within a defined growing season based on the vegetation phenology for each of the respective study area counties. Phenology metrics were derived using methods documented in Zhang et al. (2003) and Yu et al. (2004), and include green-up onset date (season start), date of growing season maximum (peak season), and dormancy onset date (season end). 


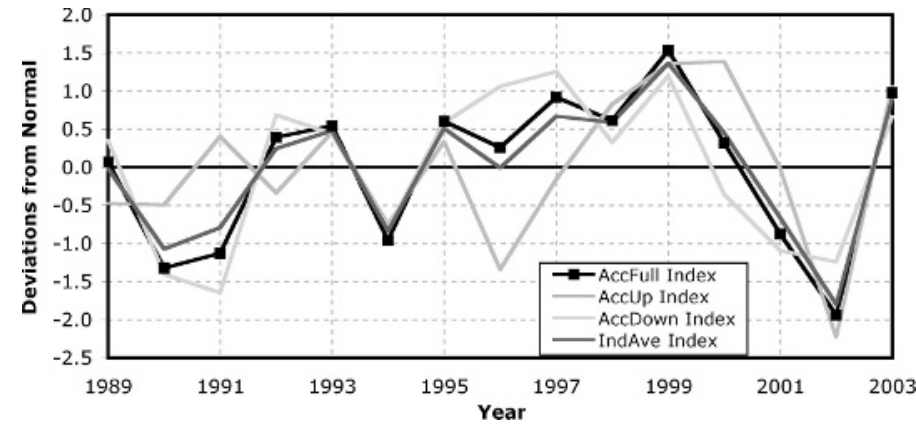

Figure 2. Four standardized rangeland insurance indices. Position relative to the 0.0 line represents "deviations from normal," with "better (worse) than normal" years indicated by positive (negative) values. See Table 1 for a description of the indices.

The 4 rangeland insurance indices based on the identified phenology metrics were 1) full season accumulated NDVI (AccFull), 2) green-up accumulated NDVI (AccUp), 3) senescence/brown-down accumulated NDVI (AccDown), and 4) an average index of the first 3 (IndAve). The first 3 were simple running totals of the county NDVI values over the respective time period and a particular year-from onset date to dormancy date, from onset date to maximum greenness date, and from maximum greenness date to dormancy date, respectively. Subtracting an average accumulated score over these 3 specific time periods from each of the yearly totals yielded a raw difference-from-normal value (Hutchinson 1991). In order to make the indices scale free and thus directly comparable, we divided each of these raw difference values by the standard deviation of the respective accumulated scores from the 15-year time series. The resulting values can be interpreted such that a score of 0 is a normal year, below 0 is a worse-than-normal year, and above 0 is a better-than-normal year, with index increments in terms of "deviations from normal." The fourth index (IndAve) is simply an annual average of the 3 standardized index values (Fig. 2). Notably, an implementation of these indices true to a GRP rangeland insurance program would require the computation of an average over all years, leaving out the 1 for which an indemnity is being calculated. For simplicity and given our purposes here, however, the whole time series was used to determine a "normal" year (for more details on computation of these rangeland insurance indices, see Rowley 2005).

For comparison purposes, we also calculated a few precipitation-based variables to investigate possible correspondences between these variables and rancher perception of rangeland production. Precipitation is, of course, a likely indicator for ranchers, particularly in years of bad range production resulting from drought. Furthermore, the strong correlation between NDVI and rainfall is well documented for the region of study (Wang et al. 2001, 2003; Ji and Peters 2004). Comparing how rainfall relates to rancher perception can help determine whether NDVI provides a worthwhile indicator for decision support in a rangeland insurance program. These precipitation variables were computed in a similar manner to the rangeland insurance indices, using monthly county averages derived from National Weather Service cooperative meteorological station data. Table 1 contains a brief description of each of the rangeland insurance indices and precipitation variables.

\section{Rancher Perception Data Collection}

Validation of remote sensing data is typically performed through some form of ground "truthing" process, most often using in situ field measurements (e.g., precipitation, temperature, biomass, leaf area) at select locations in the study area. In this research we used rancher perception of their rangeland/ pasture productivity as a similar means of validation. Ranchers arguably know their range better than anyone or anything, including field observations and remote sensing measurements. Rancher recollection and ranch records hold good potential for reconstructing historical ranch productivity. Furthermore, ranchers are going to be the ones purchasing the insurance. If their expectations, as reflected in the following analysis, are not met by a remote sensing-based decision support mechanism, then a program based on that decision support is not likely to meet large success, and many of the problems observed in the Montana pilot program will be perpetuated.

We collected perception data through an anonymous mail-in survey. The survey requested that ranchers do an assessment similar to that used in deriving the rangeland insurance indices from remote sensing imagery, only using their own memory/ ranch records as the historical database. We asked them to think back over as many years as they could recall to determine

Table 1. Description of NDVI-based rangeland insurance indices and precipitation variables. Each insurance index was standardized to a "deviations-from-normal" scale using mean and standard deviation statistics estimated from the 15-year (1989-2003) time series.

\begin{tabular}{ll}
\hline Index/variable & Description \\
\hline AccFull index & Accumulated NDVI for full growing season (from greenness onset date to date of dormancy) \\
AccUp index & Accumulated NDVI for the first half of the growing season (from greenness onset date to date of maximum greenness) \\
AccDown index & Accumulated NDVI for the second half of the growing season (from date of maximum greenness to date of dormancy) \\
Index average & An average of the above 3 indices \\
PGS & Precipitation totaled over growing season \\
PGS+7 & Precipitation totaled over extended growing season (regular growing season plus 7 months preceding growing season start) \\
PGSDev & PGS normalized to deviation-from-normal scale using average growing season precipitation total over 15-year (1989-2003) time \\
& Series \\
PGS+7Dev & PGS+7 normalized to deviation-from-normal scale using average extended growing season precipitation total over 15-year (1989- \\
& 2003 ) time series \\
\hline
\end{tabular}


Table 2. Data collected from surveys completed by ranchers. This table shows the data from the 19 responses that were useable. Each yearly rating is relative to a [-5:5] integer scale, with 0 indicating a normal year. All counties are in Kansas except where noted.

\begin{tabular}{|c|c|c|c|c|c|c|c|c|c|}
\hline Survey no. & County & $\begin{array}{l}\text { Percent of land } \\
\text { in this county }\end{array}$ & $\begin{array}{c}\text { Basis for } \\
\text { assessment* }\end{array}$ & $\begin{array}{l}\text { No. of years } \\
\text { on land }\end{array}$ & $\begin{array}{l}1999 \\
\text { rating }\end{array}$ & $\begin{array}{l}2000 \\
\text { rating }\end{array}$ & $\begin{array}{l}2001 \\
\text { rating }\end{array}$ & $\begin{array}{l}2002 \\
\text { rating }\end{array}$ & $\begin{array}{l}2003 \\
\text { rating }\end{array}$ \\
\hline 01 & Pottawatomie & 100 & 3 & 15 & 0 & 1 & -2 & -3 & -4 \\
\hline 03 & Butler & 60 & 6 & 24 & 1 & -1 & 0 & 2 & -2 \\
\hline 05 & Kiowa & 92 & 6 & 11 & 3 & 3 & 0 & -4 & -2 \\
\hline 06 & Harper & 90 & 3 & 11 & 1 & 0 & -1 & -4 & -3 \\
\hline 08 & Comanche & 100 & 1 & 9 & 0 & 0 & 0 & 1 & -1 \\
\hline 09 & Harper (OK) & 100 & 1 & 35 & 2 & 3 & 0 & -2 & -2 \\
\hline 10 & Comanche & 100 & 1 & 9 & 1 & -1 & -2 & -3 & 0 \\
\hline 11 & Comanche & 100 & 5 & 28 & 0 & 0 & -1 & 0 & -3 \\
\hline 12 & Barber & 100 & 1 & 25 & 3 & -1 & -2 & 0 & 2 \\
\hline 13 & Greenwood & 100 & 1 & 24 & 0 & 0 & 0 & 0 & -1 \\
\hline 14 & Kearny & 60 & 5 & 25 & 3 & -2 & 1 & -5 & 2 \\
\hline 15 & Barber & 100 & 2 & 40 & -2 & 1 & -5 & -2 & 0 \\
\hline 16 & Comanche & 100 & 2 & 8 & 0 & -1 & -2 & -4 & -2 \\
\hline 17 & Meade & 75 & 1 & 18 & 0 & -1 & -2 & -5 & -3 \\
\hline 18 & Kiowa & 100 & 1 & 30 & -1 & -1 & 1 & -2 & -2 \\
\hline 19 & Kiowa & 100 & 5 & 11 & 2 & -1 & -1 & -2 & -3 \\
\hline 20 & Barber & 100 & 3 & 20 & -2 & -3 & -3 & -2 & -1 \\
\hline 21 & Comanche & 100 & 5 & 12 & 0 & 0 & -3 & -2 & -1 \\
\hline 22 & Comanche & 100 & 1 & 5 & -3 & -1 & -1 & 1 & 2 \\
\hline
\end{tabular}

${ }^{*} 1=$ Recollection; $2=$ Rainfall; $3=$ 0ther ranch records; $4=$ Recollection and rainfall; $5=$ Recollection and other records; $6=$ Rainfall and other records.

"normal" years as well as those that could be characterized as extreme (very good or very bad range productivity). Using this historical perspective as a guide, they were to then rate the productivity on their rangeland/pasture for 1999 through 2003 based on how each of these recent years ranked in relation to their normal and extreme years. The ratings were to be made on a scale of 0 to 10,0 being the very worst year, 5 being a normal year, and 10 being the very best year.

The ranchers were also asked to explain the basis for their assessment (i.e., recollection or ranch records) and to give the number of years they have managed the lands for which they made their assessment. Additionally, ranchers were to list the county and state where their range/pasture is located and, if they indicated multiple counties, what proportion of their land was in each county. This additional information allowed us to put their ratings into perspective and, more important, to geographically align them with the remote sensing database.

Of the 53 surveys sent to the Comanche Pool mailing list, we received 22 responses. Three of the responses were discarded based on incompleteness of response and/or rancher's lack of time on the land (i.e., less than the 5 years to be evaluated). Given the complexity of the survey, repeated surveys were not feasible. The 19 rancher responses are undoubtedly a small subset from which to perform an analysis of rancher perception of productivity as it relates to satellite-based measurements. Furthermore, we cannot claim that such a sample can be representative of the ranching population in Kansas and Oklahoma. Our goal, however, was to understand rancher perception of range productivity through a census of an entire group rather than a random sample (the 53 producers to whom we sent the survey constituted the entirety of the CP mailing list), and the analysis that follows needs to be understood in such a light. In other words, we did not attempt to sample an entire population of ranchers in Kansas and Oklahoma or the High Plains. We instead tried to determine, in a pilot case study, how accepting a group of ranchers might be to a rangeland insurance program founded on a satellite-based measurement of rangeland productivity. Given the Comanche Pool's goals to promote conservation and economic growth, the ranchers on that group's mailing list employ, or are interested in implementation of, higher levels of rangeland management and management solutions that will assist them in making their operations economically successful (CP, no date; personal communication, 8 February 2007). Risk mitigation through rangeland and pasture insurance has the potential of becoming one of those solutions. In this facet, the producers on the Comanche Pool mailing list represent a group likely to be interested in a rangeland insurance program.

To make the rancher responses more directly comparable to the rangeland insurance indices, we subtracted 5 from each perception score from the 19 returned surveys to transform the ratings to a 0 -centered scale, where 0 is the normal year according to the rancher. The resulting number will be termed a rancher perception score, or simply a survey score. Table 2 summarizes rancher perception scores as well as data from additional survey questions. Where respondents had range/ pastureland in more than 1 county, we attributed their perception scores to only the county containing the majority of their land.

\section{Rancher Perception Data Analysis}

These rancher perception scores were then compared to the deviation-from-normal scores found through the NDVI rangeland insurance index calculations. Analysis was carried out in several stages, all of which utilized simple Pearson's productmoment correlation coefficients ( $r$ values) to quantify the 
Table 3. Correlation coefficients comparing ranch-level perception scores to 4 rangeland insurance indices over 5 years $(n=5)$. In the majority of cases, poor agreement exists at this scale. Bold $r$ values indicate cases where positive correlation is observed and at least $50 \%$ of the variance of the 5 survey-level perception scores is explained by the NDVI-based index.

\begin{tabular}{lrrrr}
\hline Survey no. & AccFull index & AccUp index & AccDown index & Index average \\
\hline 01 & 0.05 & 0.28 & -0.08 & 0.10 \\
03 & -0.56 & -0.69 & -0.45 & -0.59 \\
05 & $\mathbf{0 . 7 3}$ & $\mathbf{0 . 8 2}$ & 0.54 & $\mathbf{0 . 7 5}$ \\
06 & 0.57 & 0.70 & 0.45 & 0.60 \\
08 & -0.73 & -0.76 & -0.63 & -0.75 \\
09 & 0.51 & 0.69 & 0.32 & 0.54 \\
10 & $\mathbf{0 . 9 9}$ & $\mathbf{0 . 8 5}$ & $\mathbf{0 . 9 8}$ & $\mathbf{0 . 9 8}$ \\
11 & -0.28 & -0.24 & -0.28 & -0.28 \\
12 & $\mathbf{0 . 7 5}$ & 0.43 & $\mathbf{0 . 9 1}$ & 0.69 \\
13 & -0.33 & -0.27 & -0.26 & -0.34 \\
14 & $\mathbf{0 . 9 5}$ & $\mathbf{0 . 8 9}$ & $\mathbf{0 . 9 9}$ & $\mathbf{0 . 9 6}$ \\
15 & 0.45 & 0.44 & 0.41 & 0.45 \\
16 & $\mathbf{0 . 8 7}$ & $\mathbf{0 . 9 1}$ & $\mathbf{0 . 7 4}$ & $\mathbf{0 . 8 9}$ \\
17 & $\mathbf{0 . 9 3}$ & $\mathbf{0 . 8 8}$ & $\mathbf{0 . 8 1}$ & $\mathbf{0 . 9 3}$ \\
18 & -0.17 & 0.11 & -0.40 & -0.13 \\
19 & 0.47 & 0.35 & 0.50 & 0.45 \\
20 & 0.35 & 0.03 & 0.56 & 0.29 \\
21 & $\mathbf{0 . 7 5}$ & 0.67 & $\mathbf{0 . 7 4}$ & $\mathbf{0 . 7 5}$ \\
22 & -0.37 & -0.41 & -0.29 & -0.38 \\
Mean $r$ value & 0.31 & 0.30 & 0.29 & 0.31 \\
\hline
\end{tabular}

relationship between several rancher perception score groupings and the rangeland insurance index scores. These correlation coefficients are used simply as descriptive measurements, although we arbitrarily define "strong" correlations as those where the 2 series compared have more than $50 \%$ of their variation in common (i.e., where $r \geq 0.71$ ).

\section{RESULTS AND DISCUSSION}

\section{Ranch-Level Analysis}

When comparing individual rancher perception scores to that ranch's county-level NDVI score, correlations were generally poor (Table 3). In most cases, a relationship between the 2 is nonexistent. As such, it is impossible to draw definitive conclusions on the relationship between individual rancher perception and rangeland insurance indices based solely on these results. Mean correlation coefficients for all survey/ rangeland insurance index comparisons confirm this (Table 3). However, in the case of surveys $10,14,16$, and 17 , a strong relationship exists between rancher perception and all NDVIderived indices. In the case of survey 14, a strong relationship also was found between the rancher perception scores and all precipitation variables. Although not shown, correlation coefficients for individual rancher perception versus precipitation variables are similar in magnitude to those reported in Table 3 and thus are similarly unconvincing.

We also desired a study area wide view of individual rancher perception versus NDVI-based indices. To that end, we

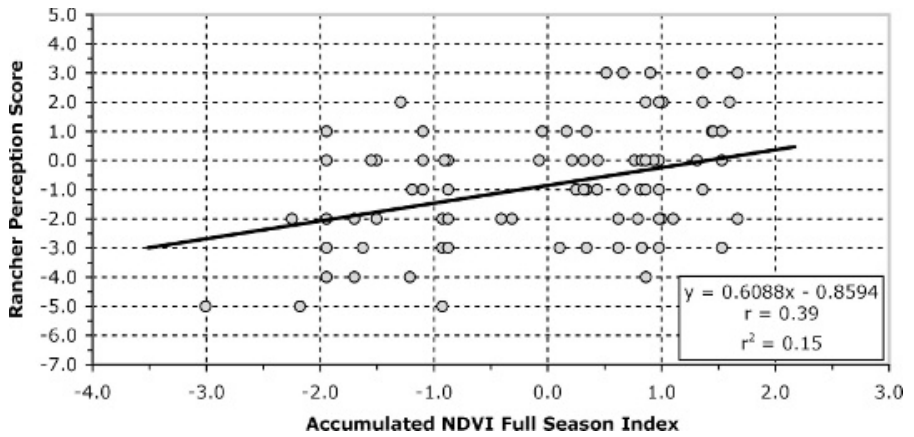

Figure 3. Plot showing the linear relationship between individual rancher perception scores and the NDVI-based full season index $(n=95)$ to show the overall pattern of agreement for the entire study area.

analyzed a full grouping of the data at the ranch level. This included all 5 years from all 19 surveys combined into a 95point data set. A weak linear relationship between all 95 rancher survey scores and rangeland insurance indices was evident (Fig. 3). Correlation coefficients were 0.39, 0.39, 0.35, and 0.40 for individual rancher perception versus AccFull, AccUp, AccDown, and Index Average, respectively. Based on these $r$ values, at best a marginally substantial relationship was observed between individual rancher perception and countylevel, NDVI-based indices.

We also computed a study area average by year based on the entire set of ranch-level survey scores. The result was 5 perception scores, each representing a yearly average of all 19 survey scores for that year. The rangeland insurance indices and precipitation variables were also aggregated to a study area score using a weighted average based on the number of surveys received per county. For example, since there were 6 surveys from Comanche County, Kansas, each rangeland insurance index (and precipitation variable) for that year and county received a weight of 6/19 in the weighted average. This method allowed the rangeland insurance indices to have the same influence on the study area average as did the survey scores.

Analysis of this study area aggregation yielded stronger correlations. Correlation coefficients comparing average rancher perception scores to corresponding average rangeland insurance indices were as follows: AccFull, 0.80; AccUp, 0.79; AccDown, 0.73; and Index Average, 0.81 (Fig. 4). The increase in $r$ value was expected, knowing that by aggregating geographic data in the presence of an actual underlying relationship, $r$ values will typically increase (Clark and Hosking 1986). Despite the fact that $n=5$ in this assessment, the overall strong relationship was nonetheless encouraging. When comparing precipitation variables and rancher perception in this same study area aggregation, we found $r$ values of $0.30,0.97$, 0.29 , and 0.95 for rancher perception versus PGS, PGS+7, PGSDev, and PGSDev+7, respectively.

\section{County-Level Analysis}

Underlying the main goal of this study was the application of this analysis in a proof-of-concept frame for a GRP-patterned insurance program based on NDVI measurements. As such, analysis of a county-level measure of perception is potentially 


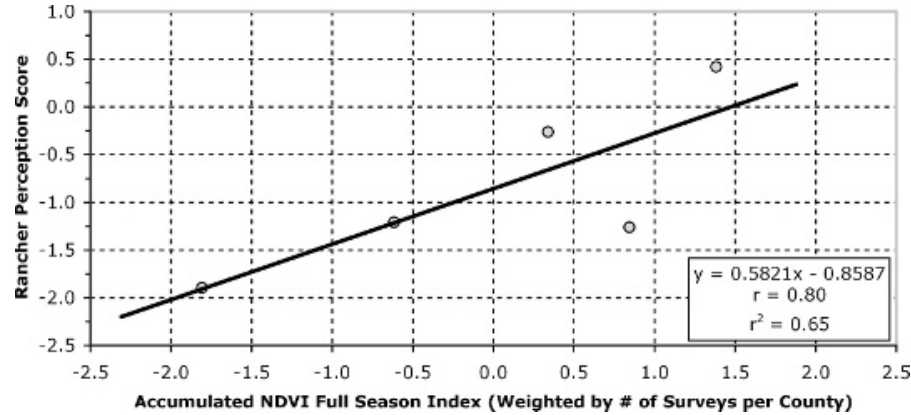

Figure 4. This plot shows the relationship between the all-survey average rancher perception score and the corresponding average NDVIbased full season index $(n=5)$.

the most important spatial scale to consider. Unfortunately, we have multiple survey responses for only 3 counties. These 3 county scores, however, represent rancher perception scores from 12 of the 19 surveys received: 3, 6, and 3 surveys from Barber, Comanche, and Kiowa counties, respectively. Mean $r$ values of the ranch-level correlation results for these 12 surveys are nearly identical to those reported for the whole 19-survey data set in Table 3, providing some support for the notion that the 12-point subset is representative of the full 19-point perception data set.

For each of these 3 counties, we created a county-level perception score by calculating the mean of the survey scores, which were then compared to that county's NDVI score. These derived scores reflect, at least in our small sample, what the traditional GRP program implements in a 1-yield-per-county determination of how much, if any, loss is incurred by all in the county. The combined perception for rangeland production in the county should be closely related to the index from which indemnity payments are determined/calculated if the program is to be generally acceptable to the ranchers who buy its coverage.

In spite of the limited sample size ( $n=5$ for each evaluation), the correlation between rancher perception and rangeland insurance index generally improved when aggregating to a county-level perception score (Table 4). Also, the fact that the county with the most observations (Comanche County, 6 surveys) demonstrated the best overall results provides some weak evidence that the correspondence between county-level rancher perception and NDVI might improve as more surveys are considered.

\section{Comparing Ranch-Level and County-Level Results}

The differences between the ranch-level correlations and those at the county level illustrate the major shortcoming of a countylevel GRP framework for rangeland insurance. The agreeability between the multisurvey county-level averages of rancher perception and the rangeland insurance indices generally supports the use of remote sensing-based decision support for rangeland and pasture insurance; that is, the county-level rangeland insurance index appears to reasonably reflect the county-level perception of productivity. Yet, undeniable is the fact that the perceptions of a number of individual ranchers do not correlate well with the county-level rangeland insurance indices (Table 3). This is due primarily to the substantial ranchlevel variability that would be generally expected within counties of appreciable size such as those comprising this study. The rangeland insurance index typically takes into account a much larger and more diverse area than a single ranch. Barnett (2004) pointed out that an index can lead to an increase in risk if no significant correlation exists between farm-level (ranch-level) yields and the area-based (county-level) index measurement. Because the scale discrepancy is an inherent part of any GRP insurance product, the lack of correlation between most surveys and their county-level index is discouraging and confirms the problem described by Barnett (2004). As such, additional research needs to look into methods of reducing the area in an area-based index measurement to a size closer to that of the ranch (see Atwood et al. 2005).

\section{Yearly Groupings}

Referring back to Figure 2, notice that the rangeland insurance indices show that, in the time span between 1999 and 2003, there were-at least according to the NDVI data-instances of good, normal, and bad years. According to the survey response and general knowledge from those years, this is close to what was actually experienced. In this last stage of analysis, we evaluated how well NDVI-derived indices correlated with rancher perception of rangeland production for specific years. To accomplish this, we broke the county-level data into 5 groups-representing the 5 years in the study-of 10 observations each, 1 per county. In addition to the multisurvey counties, counties with a single survey (which represented the county-level average) were also considered in this assessmenteach of the 10 county-level scores getting equal weight-so that all survey responses were used. This stage of the analysis answered an important question in the larger context of providing decision support to a rangeland insurance program: If ranchers feel that a particular year had been a less-than-

Table 4. Correlation coefficients comparing mean county perception scores in the 3 Kansas counties for which there were multiple surveys to rangeland insurance indices and precipitation variables $(n=5)$. Bold $r$ values indicate cases where positive correlation is observed and at least $50 \%$ of the variance of the 5 county-mean perception scores is explained by the NDVI-derived score.

\begin{tabular}{|c|c|c|c|c|c|c|c|c|}
\hline & AccFull index & AccUp index & AccDown index & Index average & PGS & PGS+7 & PGSDev & PGS+7Dev \\
\hline Barber County (Surveys 12, 15, 20) & 0.75 & 0.53 & 0.84 & 0.72 & 0.43 & 0.72 & 0.43 & 0.72 \\
\hline $\begin{array}{l}\text { Comanche County (Surveys } 08,10,11,16 \text {, } \\
21,22 \text { ) }\end{array}$ & 0.82 & 0.73 & 0.80 & 0.82 & 0.48 & 0.79 & 0.48 & 0.79 \\
\hline Kiowa County (Surveys $05,18,19$ ) & 0.55 & 0.62 & 0.41 & 0.57 & 0.33 & 0.57 & 0.33 & 0.57 \\
\hline 3-county mean $r$ value & 0.71 & 0.63 & 0.68 & 0.70 & 0.41 & 0.70 & 0.41 & 0.70 \\
\hline
\end{tabular}


Table 5. Correlation coefficients comparing year-specific, county average rancher perception scores to rangeland insurance indices and precipitation variables $(n=10)$. The year 2002, which many considered to be the worst drought year in the past decade, is when the highest correlations were observed for 6 of the 8 rangeland productivity proxies.

\begin{tabular}{lccccrrrr}
\hline & AccFull index & AccUp index & AccDown index & Index average & PGS & PGS+7 & PGSDev & PGS+7Dev \\
\hline County averages, 1999 & -0.02 & -0.32 & 0.31 & 0.00 & -0.39 & -0.40 & -0.19 & -0.25 \\
County averages, 2000 & 0.35 & 0.31 & 0.34 & 0.42 & 0.01 & -0.05 & 0.11 & -0.02 \\
County averages, 2001 & 0.21 & 0.08 & 0.22 & 0.19 & 0.12 & -0.02 & 0.42 & 0.41 \\
County averages, 2002 & 0.55 & 0.69 & 0.22 & 0.60 & 0.63 & 0.67 & 0.32 & 0.49 \\
County averages, 2003 & 0.38 & 0.28 & 0.19 & 0.36 & -0.48 & -0.45 & -0.25 & -0.14 \\
\hline
\end{tabular}

normal one and that they deserve an indemnity payment, is this perception supported by the rangeland insurance index trigger mechanism?

Correlation coefficients for rancher perception versus NDVI with data stratified by year are shown in Table 5 (with rancher perception versus precipitation included as well). Note that the strongest correlations were for 2002, which is considered to be the nadir of the most recent drought. In fact, with precipitation variables included, only in 2 of 8 cases (one each for NDVI and precipitation) was the highest $r$ value found in a year other than 2002. This was encouraging since it shows that in the worst drought year, from this sample, the rangeland insurance indices were good predictors of rancher perception. This adds a measure of confidence to the use of these indices in rangeland insurance decision support. A generally positive but weaker linear relationship exists between rancher perception and NDVI in other years. Although the precipitation variables also produced the best results in 2002 (attaining $r$ values similar to NDVI), results from other years are generally more discouraging than NDVI results from those years.

Two assumptions can be made about how rancher perception compares to measurements from NDVI and precipitation. First, one might assume that low-productivity years would be more memorable to ranchers, causing them to more accurately rate the bad years (presuming that any "exaggerative" effect that might be likewise associated with such years is weak). Second, one could assume that a rancher would more accurately rate recent years, at least in the case of recollection-based ratings (the majority of rancher ratings were made wholly or in part on the basis of recollection).

Figure 5 shows the general patterns and relationships, at the study area level, between overall rancher perception, 2 rangeland indices, and 1 precipitation variable. The larger the gap between the points in the rangeland insurance index lines and the top (or bottom) of the bars, the smaller the agreement between rancher perception and the proxy in question. With the first assumption in mind, we would hope that an index would most closely match rancher perception in the least productive years. Looking at this graph and Table 5, this seems to be the case, as 2002 is regarded as the worst year in the near past and certainly in the years of study here. At the same time, however, ranchers saw 2003 as a year well below normal, while NDVI showed it to be an above-normal year.

The reasons behind the discrepancy between NDVI and perception in 2003 cannot be ascertained without additional analysis, but we have considered one hypothesis. Ranchers' perception of the 2003 growing season productivity may have been based on the timing of rainfall and greenness events. In July of that year, there was a significant drop in precipitation throughout the study area, resulting in a drop in NDVI values below the long-term average in late July and early August. A deluge of rain in August then brought a subsequent increase in greenness late in the growing season (Fig. 6). Our indices did not identify this midseason disaster that was flanked by a good start and a hearty recovery; each index is based on a sum of NDVI values for all or a large portion of the growing season, which, in effect, lessens the impact of relatively short-lived events like the one that occurred in July and August 2003. As the decline occurred during the height of the season, ranchers potentially (and perhaps appropriately if early and late season production has less utility than peak season production) saw the drop that year as more than just an isolated disaster, but as affecting the entire growing season, leading them to rate 2003 as a low-productivity year. This calls into question our partitioning the growing season into relatively large chunks for rangeland insurance indices. Were an additional NDVIderived index more concentrated and defined around the peak portion of the growing season, better agreement with rancher perception likely would have been observed in 2003. Ongoing research is exploring how to optimally define the growing season for implementation in a crop insurance program for rangeland and pasture.

In the second of the previously mentioned assumptions, we would hope that correlations would increase for recent years (Fig. 7). A general increasing pattern in the $r$ values does exist between 1999 and 2003. Although not displayed on this graph, the $r$ values reported in Table 5 for rancher perception versus

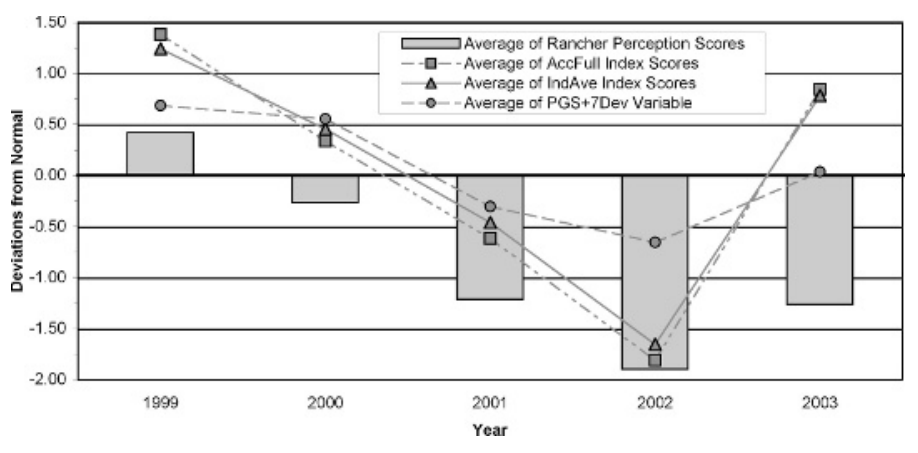

Figure 5. Graphical representation of how 2 NDVI-based indices and 1 precipitation variable resemble rancher perception. The bold 0 line on the $y$-axis represents a normal year for all graphed variables. Ranchers felt 2003 to be a "below normal" year, which was not the case in any of the depicted proxies. 


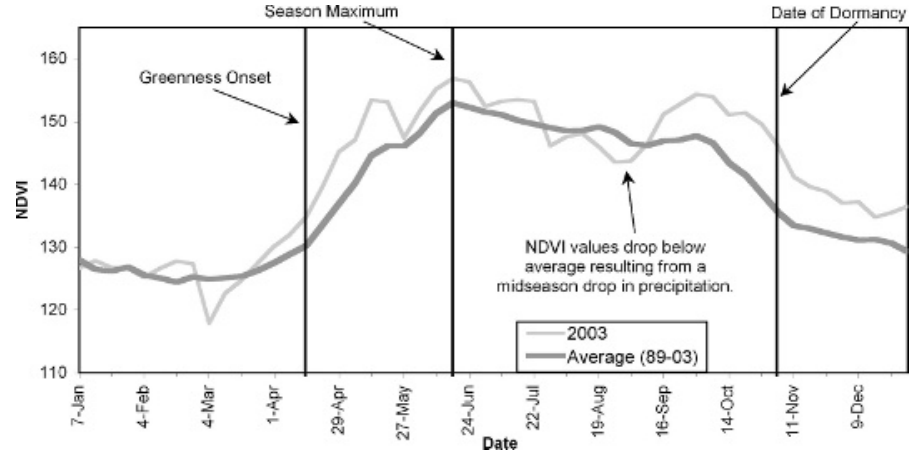

Figure 6. NDVI growing season profile for 2003 with average timeseries profile (1989-2003). Note the subaverage NDVI values occurring midseason. A focusing of the growing season more on peak season activity would give these below-average NDVI values more weight in the insurance index and thus better align the index with rancher perception results from 2003.

precipitation variables show an even larger drop in correlation between 2002 and 2003. In fact, the $r$ value for 2003 shows a negative correlation, which leads us to wonder, once again, if taking into account the deluge of rain in August 2003 may also provide some explanation for this anomaly. As with the NDVIbased indices, there is also likely some optimization work to be done with respect to identifying more appropriate precipitation variables.

Addressing these 2 assumptions provokes interesting questions: Since 2002 was such a bad year for most ranchers, were they biased by its impacts in expecting 2003 to be bad also? And did that expectation lead them to believe that it was not a "good enough" year, even though both rainfall and vegetation growth were higher in 2003 as indicated by rainfall and NDVI measurements? Did the timing of greenness and precipitation in 2003 contribute to ranchers' perception of range production that our NDVI- and precipitation-derived indices did not take into account? Or does a flush of green following a disaster year inappropriately (for insurance purposes) inflate the NDVI range indices? To investigate these lingering questions, additional data need to be collected from ranchers. In addition to simply sending out more surveys,

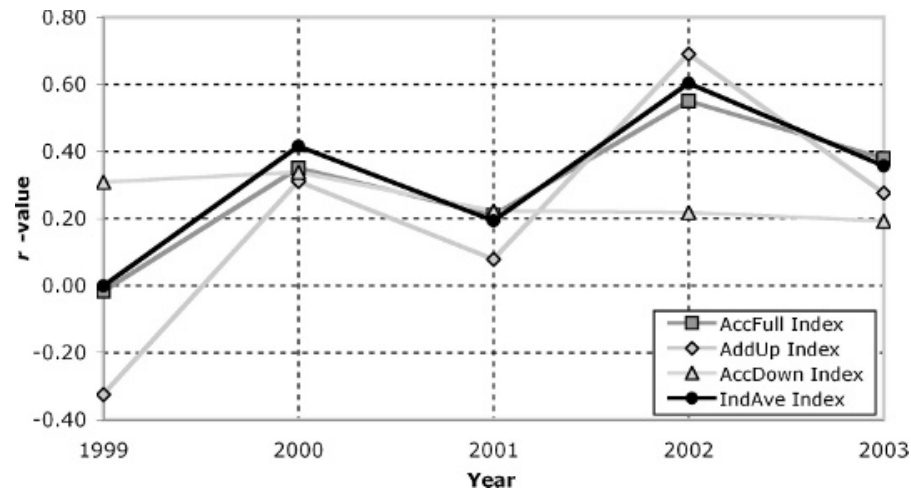

Figure 7. Correlation coefficients from rancher perception versus 4 rangeland insurance indices for the yearly grouping of county average data charted over the 5 study years. A general upward trend exists in the strength of the relationship (except the AccDown Index), which is expected. More interesting is that the highest $r$ value is in the worst drought year of the study period. personal interviews with respondents and collection of ranch production data may also prove helpful to better understand survey responses, particularly in answering the questions raised by the results from the 2003 growing season.

\section{NDVI-Based Indices Versus Precipitation}

We have presented evidence indicating that NDVI performs comparably to precipitation as an indicator of rancher perception. This was somewhat expected given the already established and well-understood relationship between NDVI and rainfall and given our own findings that the PGS+7 and PGS+7Dev variables were highly correlated with county-level NDVI-based rangeland insurance indices $(r=0.90$ for a total study area averaged, 15-year comparison of AccFull and PGS+7Dev). Arguably, however, NDVI remains a better candidate for a proxy measure of relative rangeland productivity given 2 inherent advantages: 1) NDVI is a direct measurement of vegetation properties and not an indirect measure of the response of vegetation to moisture, and 2) NDVI does not require interpolation in order to gain a measurement at a fine scale (i.e., square-kilometer grid cells). Regardless, additional study is required to determine if NDVI and precipitation information can be used in a complementary fashion or if there is a clear preference to use one or the other in a particular rangeland insurance program design.

\section{CONCLUSIONS AND IMPLICATIONS}

From a small group of 19 surveyed ranchers in Kansas and Oklahoma, we have found evidence that rancher perception of rangeland production can be partially explained with a proxy yield measurement derived from AVHRR NDVI satellite data. We have shown that a county-level measurement from the imagery positively relates to overall perception of ranchers in that county. When the entire data set is viewed at a study area scale, an even stronger correlation exists. At the same time, as evidenced in ranch-level analysis, county-based proxy measurements of rangeland productivity are not likely to satisfy some individual producers, given the geographic variation in locally relative vegetation patterns in a county attributable mainly to localized climate variations. This problem will be exacerbated in states, particularly in the West, where county sizes are much larger than those in Kansas and Oklahoma, degrading the effectiveness of the county-scale indemnity trigger. Smallerthan-county partitions will be a necessary solution should an area-based GRP insurance program be implemented on a nationwide basis. We also found that our satellite-based rangeland insurance indices best correlated with rancher perception in the worst drought year from the study period.

Given these conclusions, we feel that a remote sensing-based approach in a nationwide rangeland and pasture insurance program provides a feasible solution to the problems facing implementation of such a program. The data are readily available, and, as we have shown, a set of rangeland insurance indices derived from those data demonstrate reasonable correspondence with assessments made by a group of producers potentially likely to purchase the coverage. Generally speaking, we have shown that remote sensing can provide a proxy 
measurement for rangeland productivity that is computed with relative ease and performs comparably to precipitation information at the county level; other means of gaining such a measurement are typically inconvenient (i.e., prohibitively expensive in some way) and/or indirect and fraught with confounding variability.

More important, our research contributes to an overall effort to bring a crop insurance program to ranchers. Realization of such a program on a national scale will likely have an enormous impact on how rangeland and pasture is managed in the United States. Rangeland insurance offers an additional risk mitigation option for ranchers. This is significant in that traditionally, as Paul Starrs (1998) noted, ranchers have not been recipients of financial help from the federal government in times of drought, storms, or other climactic disasters. A payment after a loss of forage at the hand of a storm or drought can decrease the overall impact of such a disaster, allowing a rancher to keep the business going until difficulties pass. If administered appropriately and effectively, a rangeland and pasture insurance program places a new option before the rancher that could help them economically and aid in the preservation of their way of life.

\section{ACKNOWLEDGMENTS}

The authors would like to thank James Shortridge, Xingong Li, and Rachel Rowley for their assistance in earlier drafts of the manuscript as well as Loren Graff and the board of the Comanche Pool Prairie Resource Foundation for allowing us access to that foundation's mailing list. We would also like to thank the anonymous reviewers and editors for their helpful suggestions.

\section{LITERATURE CITED}

AL-BakRI, J. T., AND J. C. TAYLOR. 2003. Application of NOAA AVHRR for monitoring vegetation conditions and biomass in Jordan. Journal of Arid Environments 54:579-593.

[ARPA] Agricultural Risk Protection Act. 2000. Agricultural Risk Protection Act of 2000. Washington, DC: 106th Congress of the United States of America, Second Session. $99 \mathrm{p}$.

Atwood, J., T. Watts, K. Price, and J. Kastens. 2005. The big picture-satellite remote sensing applications in rangeland assessment and crop insurance. Speech at Agricultural Outlook Forum; 24 February 2005; Arlington, VA.

Barnett, B. J. 2000. The U.S. federal crop insurance program. Canadian Journal of Agricultural Economics 48(4):539-551.

BARNETT, B. J. 2004. Agricultural index insurance products: strengths and limitations. Speech at Agricultural Outlook Forum; 19 February 2004 Arlington, VA.

Buchanan, R. C., and J. R. McCauley. 1987. Roadside Kansas: A traveler's guide to its geology and landmarks. Lawrence, KS: University Press of Kansas. 365 p.

Cameron, S. 2002. Crop insurance for new and specialty crops. In: Proc. Future Farms 2002. 15-16 November 2002. Norman, OK: Kerr Center for Sustainable Agriculture. p. 65-72.

ClaRK, W. A., AND P. L. Hosking. 1986. Statistical methods for geographers. New York, NY: John Wiley and Sons. $518 p$.

[CP] Comanche Pool Prairie Resource Foundation. No date. Organizational statement of purpose and history.

EIDENSHINK, J. C. 1992. The 1990 conterminous U.S. AVHRR data set. Photogrammetric Engineering and Remote Sensing 58(6):809-813.
EIDENSHINK, J. C. 2006. A 16-year time series of $1 \mathrm{~km}$ AVHRR satellite data of the conterminous United States and Alaska. Photogrammetric Engineering and Remote Sensing 72(9):1027-1035.

Heat-Moon, William Least. 1999. PrairyErth (a deep map). New York, NY: Mariner Books. 624 p.

HoBBS, T. J. 1995. The use of NOAA-AVHRR NDVI data to assess herbage production in the arid rangelands of central Australia. International Journal of Remote Sensing 16(7):1289-1302.

Holben, B. N. 1986. Characteristics of maximum-value composite images from temporal AVHRR data. International Journal of Remote Sensing 7(11): 1417-1434.

Hutchinson, C. F. 1991. Uses of satellite data for famine early warning in subSaharan Africa. International Journal of Remote Sensing 12(6):1405-1421.

JI, L., AND A. J. Peters. 2004. A spatial regression procedure for evaluating the relationship between AVHRR-NDVI and climate in the northern Great Plains. International Journal of Remote Sensing 25(2):297-311.

KüCHLER, A. W. 1974. A new vegetation map of Kansas. Ecology 55(5):586-604.

LOoKER, D. 2003, August. Protected pasture. Successful Farming. 28-32.

Price, K. P., D. A. Pyke, and L. Mendes. 1992. Shrub dieback in a semiarid ecosystem: The integration of remote sensing and geographic information systems for detecting vegetation change. Photogrammetric Engineering and Remote Sensing 58(4):455-463.

ReEves, M. C., J. C. WinsLow, and S. W. Running. 2001. Mapping weekly rangeland vegetation productivity using MODIS algorithms. Journal of Range Management 54:A90-A105.

[RMA] Risk Management Agency. 2003. Crop policies. Available at: http:// www.rma.usda.gov/policies. Accessed 22 September 2003.

[RMA] Risk Management Agency. 2004. Statement of objective for research and development for risk management products for pasture/rangeland and forage. Kansas City, MO, US Department of Agriculture, Risk Management Agency. $16 \mathrm{p}$.

RowLEY, R. J. 2005. Insuring the range: Toward a crop insurance program for rangeland and pasture [thesis]. Lawrence, KS: University of Kansas. 118 p.

Schoewe, W. 1949. The geography of Kansas-part II, physical geography. Transactions of the Kansas Academy of Science 52(3):261-333.

StARRS, P. F. 1998. Let the cowboy ride. Baltimore, MD: Johns Hopkins University Press. $356 \mathrm{p}$.

Tucker, C. J., C. L. Vanpraet, M. J. Sharman, and G. Van Ittersum. 1985. Satellite remote sensing of total herbaceous biomass production in the Senegalese Sahel: 1980-1984. Remote Sensing of Environment 17(3):233-249.

TuelleR, P. T. 1989. Remote sensing technology for rangeland management applications. Journal of Range Management 42(6):442-453.

Vogelmann, J. E., S. M. Howard, L. Yang, C. R. Larson, B. K. Wylie, and N. Van Driel. 2001. Completion of the 1990s National Land Cover Data Set for the conterminous United States from Landsat Thematic Mapper data and ancillary data sources. Photogrammetric Engineering and Remote Sensing 67(6): 650-661.

Wang, J., K. P. Price, and P. M. RICh. 2001. Spatial patterns of NDVI in response to precipitation and temperature in the central Great Plains. International Journal of Remote Sensing 22(18):3827-3844.

Wang, J., P. M. Rich, And K. P. Price. 2003. Temporal responses of NDVI to precipitation and temperature in the Great Plains, USA. International Journal of Remote Sensing 24(11):2345-2364.

Wang, J., P. M. Rich, K. P. Price, and W. D. Kettle. 2005. Relations between NDVI, grassland production, and crop yield in the central Great Plains. Geocarta International 20(3):5-11.

Yu, F., K. P. Price, J. Ellis, and D. Kastens. 2004. Satellite observations of the seasonal vegetation growth in Central Asia: 1982-1990. Photogrammetric Engineering and Remote Sensing 70(4):461-469.

Zhang, X., M. A. Friedl, C. B. Schaaf, A. H. Strahler, J. C. F. Hodges, F. Gao, B. C. Reed, And A. Huete. 2003. Monitoring vegetation phenology using MODIS. Remote Sensing of Environment 84(3):471-475. 